\title{
Life cycle assessment of dryland paddy farming in Ngadirojo District, Pacitan
}

\author{
Priyaji Agung Pambudi ${ }^{1, *}$ and Tarsoen Waryono ${ }^{2}$ \\ ${ }^{1}$ School of Environmental Science, University of Indonesia, J1. Salemba Raya No. 4 Jakarta Pusat, \\ Indonesia 10430 \\ ${ }^{2}$ Department of Geography, Faculty of Mathematics and Nature Science, University of Indonesia, \\ Kampus UI Depok, Jawa Barat, Indonesia 16424
}

\begin{abstract}
The growth of weeds among agricultural crops is a pest that can decrease agricultural production by $47-87 \%$. The aims of this research is to compare organic and an organic fertilizer and compare mechanical and chemical weed and pest control. This research employed a mixed-method, observation, in-depth interviews, and life cycle assessment. The greenhouse gas emissions were released are organic fertilizer $1,87 \times 10^{-3} \mathrm{~kg} \mathrm{CO}_{2} \mathrm{eq} / \mathrm{ha}$ and an organic fertilizer $15 \times 10^{1} \mathrm{~kg} \mathrm{CO}_{2} \mathrm{eq} / \mathrm{ha}$. Thereafter greenhouse gas emissions were released from mechanical control $1,87 \times 10^{-3} \mathrm{~kg} \mathrm{CO}_{2} \mathrm{eq} / \mathrm{ha}$ and chemical control $4,4 \times 10^{1} \mathrm{~kg} \mathrm{CO}_{2} \mathrm{eq} / \mathrm{ha}$. The totally of greenhouse gas emissions was released from dryland paddy farming in management phase is $19,4 \times 10^{1} \mathrm{~kg} \mathrm{CO} 2 \mathrm{eq} / \mathrm{ha}$. Organic fertilizer more friendly than an organic fertilizer and mechanical control more friendly than chemical control. Mechanical control by farmers must be modified for the increase of effectiveness. The post-mechanical control should be those containing fruit and seed must be burned, meaning there will be not a longer any weed growth potential. Therefore, this mechanism will be able to realize potential production and sustainable dryland paddy farming.
\end{abstract}

\section{Introduction}

Dryland agriculture has become one of the solutions to the ever-increasing need for food in the midst of the rapid degradation of wetlands. In Indonesia, dryland agriculture comes in various forms. The components that build this agricultural ecosystem consist of microorganisms and macroorganisms. However, over time, the existence of the agricultural ecosystem, especially the dryland, has been threatened by the increase of weeds. This has been proven by statistical data, which reveals the productivity of dryland paddies in 2016 has decreased in the amount of $-1,44 \%$ of land paddy [1]. One possible factor that causes this decrease in agricultural crop production and productivity is the growth of weeds [2]. The weed must be managed for optimalize production and the kind of control is diverse.

\footnotetext{
* Corresponding author: priyajiagungpambudi@gmail.com
} 
Weed growth can dominate agricultural ecosystems because only a few natural herbivores live in these habitats. As a consequence, large costs are incurred by farmers treating these weeds [3]. Efforts to control the weeds should be made in an appropriate manner. Otherwise, the ecosystem may be endangered, leading to a loss of habitat for certain organisms [4]. The best solution of weed management is using life cylce assessment. It is the integratted management of all aspect in dryland paddy farming to unreleased emissions, residual, and biological explosion for environmental sustainability. It potential sector for regional development.

The existence of farming land in Pacitan Regency has great potential because, as one of the superior sectors, it provided 4.97\% PDRB in 2009 [5]. Almost 55\% of agriculture in Pacitan Regency is dryland-based, with a mainstay commodity of gogo paddies. However, the production of the paddies decreased by 4.48 ton/ha in 2015 and by 4.34 ton/ha in 2016 [6], even though dryland paddy production can ideally reach 5-7 ton/ha [7]. A decrease in dryland production can be affected by weeds, soil fertility, plant rotation, agriculture system treatment, seed quality, fertilizer, and land width $[8,9,10]$. However, the soil fertility, plant rotation, agriculture system, treatment, seed quality, and fertilizer that have been used in these paddies has remained the same. Therefore, the main factor that causes a decrease in agricultural production is the growth of weeds. Another negative impact of the existence of the weeds is an unfriendly control with chemical technique like herbicide and pesticide. The chemical control by a farmer's implemented can cause each 10-12\% global greenhouse gas (GHG) total [11] and the degradation of ecosystems.

\section{Method}

The methods used is a mixed method, observation, and in-depth interview. We are used life cycle assessment to compare the impact of mechanical control and chemical control for the environment. The research was conducted in dryland paddy farming in Ngadirojo district, Pacitan Regency, East Java on June-October 2018. We are the focus on dryland paddy farming management namely fertilization, weed, and pest control.

\subsection{Board and purposing pursuit of research}

The environmental impact that counts is Global Warming Potential (GWP) like Greenhouse Gas Emission that was released from agricultural management. The unit function uses for greenhouse gases is $\mathrm{kg} \mathrm{CO}$ eq/ha. The research scope is in figure 1.

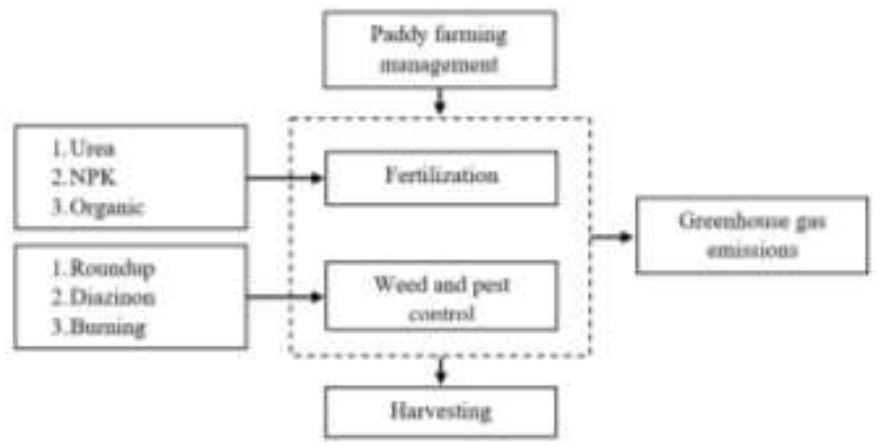


Fig. 1. LCA scope in paddy farming management.

\subsection{Inventory of life cycle in paddy farming}

Paddy farming proces were waste solid, slushy, and gas produce. As an aims all of the waste was convert in greenhouse gas emission unit function $\left(\mathrm{kg} \mathrm{CO}_{2} \mathrm{eq}\right)$. The calculation of total emissions is:

$\mathrm{EM}_{\text {Total }}=\mathrm{EM}_{\mathrm{NPK}}+\mathrm{EM}_{\mathrm{Urea}}+\mathrm{EM}_{\mathrm{Rdp}}+\mathrm{EM}_{\text {Dzn }}+\mathrm{EM}_{\text {Org.Fert }}+\mathrm{EM}_{\text {Burn }}$.

Explanation:

$\mathrm{EM}_{\text {Total }} \quad$ : Total emission released $\left(\mathrm{kg} \mathrm{CO}_{2} \mathrm{eq} / \mathrm{ha}\right)$

$\mathrm{EM}_{\mathrm{NPK}} \quad$ : NPK emission released $\left(\mathrm{kg} \mathrm{CO}_{2} \mathrm{eq} / \mathrm{ha}\right)$

EM $_{\text {Urea }}$ : Urea emission released $\left(\mathrm{kg} \mathrm{CO}_{2} \mathrm{eq} / \mathrm{ha}\right)$

$\mathrm{EM}_{\mathrm{Rdp}} \quad$ : Roundup emission released $\left(\mathrm{kg} \mathrm{CO}_{2} \mathrm{eq} / \mathrm{ha}\right)$

$\mathrm{EM}_{\text {Dzn }}:$ Diazinon emission released $(\mathrm{kg} \mathrm{CO} 2 \mathrm{eq} / \mathrm{ha})$

EM $_{\text {Org.Fert }}$ : Organic fertilizer emission released $\left(\mathrm{kg} \mathrm{CO}_{2} \mathrm{eq} / \mathrm{ha}\right)$

$\mathrm{EM}_{\mathrm{Burn}} \quad$ : Burning emission released $\left(\mathrm{kg} \mathrm{CO}_{2} \mathrm{eq} / \mathrm{ha}\right)$

Table 1. Emissions factor per unit emissions.

\begin{tabular}{lccc}
\hline No & Sources of emissions & $\mathbf{k g ~ C O} \mathbf{~ e q} / \mathbf{u n i t}$ & Reference \\
\hline 1 & NPK & $3 \times 10^{-3}$ & {$[12]$} \\
2 & Urea & $5,42 \times 10^{-3}$ & {$[13]$} \\
3 & Roundup & $11,02 \times 10^{1}$ & {$[14]$} \\
4 & Diazinon & $11,02 \times 10^{1}$ & {$[15]$} \\
5 & Residue of organic fertilizer & $1,62 \times 10^{-6}$ & {$[16]$} \\
6 & Burning & $7,83 \times 10^{-6}$ & {$[17]$} \\
\hline
\end{tabular}

\section{Result and discussion}

\subsection{Fertilization}

Paddy farming were divided for fertilization, weed and pest management. Farmers used organic like manure and an organic fertilizer like NPK and Urea in twice phase of paddy farming. Furthermore, their manage the weeds and pests with mechanical control like burning and chemical control used Roundup and Diazinon (two kinds of pesticide). Research scope is a management of paddy farming not land preparation, planting, and harvesting.

Table 2. Greenhouse gas emissions in fertilization process.

\begin{tabular}{|c|c|c|c|}
\hline No & Sources of emissions & Number of uses & $\left(\mathrm{kg} \mathrm{CO}_{2} \mathrm{eq} / \mathrm{ha}\right)$ \\
\hline \multicolumn{4}{|c|}{ Organic fertilizer } \\
\hline 1 & Organic fertilizer (manure) & $85 \mathrm{~kg}$ & $1,87 \times 10^{-3}$ \\
\hline \multicolumn{3}{|c|}{$\begin{array}{l}\text { Total emission } \\
\end{array}$} & $1,87 \times 10^{-3}$ \\
\hline \multicolumn{4}{|c|}{ An organic fertilizer } \\
\hline 1 & NPK & $15 \mathrm{~kg}$ & $6 \times 10^{-1}$ \\
\hline 2 & Urea & $20 \mathrm{~kg}$ & $14,4 \times 10^{1}$ \\
\hline \multicolumn{3}{|c|}{ Total emissions } & $15 \times 10^{1}$ \\
\hline
\end{tabular}


Organic fertilizer more environmental friendly than an organic fertilizer. This matter caused by total emissions from an organic fertilizer is very large. Based on comparison mechanism of fertilization organic is the solution for reducing greenhouse gas emission from paddy farming. The component of organic fertilizer easily for land absorbed [18], it can crop utilized for growth. However, chemicals component on an organic fertilized not perfectly absorbed, so the residue will be emitted to the atmosphere.

\subsection{Weed and pest management}

The very dangerous weed is Alternanthera sessilis (L.) R.Br. Ex DC. This species has the ability to spread widely and the potential for massive growth even in the dry or rainy season. The danger is greater in the rainy season because Alternanthera sessilis (L.) R.Br. Ex DC can cover $90 \%$ of the farming land surface. The species can rapidly spread through generative (flat seed) and vegetative (stem cutting) propagation [19]. The farmers said that controlling this weed is exhausting, particularly in the period of preparing the farming land and during the early planting period. Generally, farmers involve their wife for weed control, this condition was implemented from generation to generation. Women involvement in agriculture is most crucial to integrated social and environmental aspect [20]. Especially in the farming land preparation phase at this time, their decision whether the land is ready or not [21]. During this phase, farmers should have ensured that the plant is free from Alternanthera sessilis (L.) R.Br. Ex DC, so that the agricultural crop can grow optimally.

At present, the control method commonly employed by farmers is the mechanical control of clearance by hoeing. This technique is effective enough to get rid of the covering of Alternanthera sessilis (L.) R.Br. Ex DC on the surface of the farming land during the land preparation phase. Nevertheless, farmers said that, if there is a root or stem of Alternanthera sessilis (L.) R.Br. Ex DC remaining, then it will grow again, provided that there is water in the land, causing a greater threat to the life of agricultural crops [22]. Weeds and pests are the crops disturbances and contribute for decreased production. Farmers strive to manage the existence in order to optimization yields. Table 3 is the comparison of emissions the weed and pest management in dryland paddy farming.

Table 3. Greenhouse gas emissions in weed and pest control.

\begin{tabular}{|c|c|c|c|}
\hline No & Sources of emissions & Number of uses & $\left(\mathrm{kg} \mathrm{CO}_{2} \mathrm{eq} / \mathrm{ha}\right)$ \\
\hline \multicolumn{4}{|c|}{ Mechanical control } \\
\hline 1 & Burning & $18 \mathrm{~kg}$ & $1,87 \times 10^{-3}$ \\
\hline \multicolumn{3}{|c|}{ Total emission } & $1,87 \times 10^{-3}$ \\
\hline \multicolumn{4}{|c|}{ Chemical control } \\
\hline 1 & Roundup & $0,02 \mathrm{~kg}$ & $2,93 \times 10^{1}$ \\
\hline 2 & Diazinon & $0,01 \mathrm{~kg}$ & $1,47 \times 10^{1}$ \\
\hline \multicolumn{3}{|c|}{ Total emissions } & $4,4 \times 10^{1}$ \\
\hline
\end{tabular}

Roundup and Diazinon are popularly herbicide uses in Ngadirojo district as a chemical control. Chemical control uses by some farmers because this mechanism is easy, inexpensive, and effective. Nevertheless, chemical control has a negative impact for ecosystem [23]. So, other farmers prefer for implemented mechanical control as an effort to keep the sustainable of the ecosystem. Farmers said that the mechanical control is chosen for three reasons; they are controlling weeds; converted the weeds into compost fertilizer; and using it to feed livestock, the feces of which will be used as manure. For this reason, the mechanical control method applied by the farmers is ideal. Farmers know that weeds 
have biomass and elements of C-Organic, which have the role of inputting soil nutrients [24], so they control the weeds such that they are less harmful to the environment by hoeing and then turning the weeds into compost fertilizer and livestock feeding. Weeds can be turned into compost because they have a high proportion of C-Organic, so they have the role of fertilizing the soil [25]. The next day, livestock feces will be converted for manure and used on the same land. This mechanism can reduce greenhouse gas emissions in large quantities.

Table 4. Totally greenhouse gas emissions from dryland paddy farming (in management phase).

\begin{tabular}{cccc}
\hline No & Sources of emissions & Number of uses & $(\mathbf{k g ~ C O} \mathbf{~ e q} / \mathbf{h a})$ \\
\hline 1 & Organic fertilizer (manure) & $85 \mathrm{~kg}$ & $1,87 \times 10^{-3}$ \\
2 & NPK & $15 \mathrm{~kg}$ & $6 \times 10^{-1}$ \\
3 & Urea & $20 \mathrm{~kg}$ & $14,4 \times 10^{1}$ \\
4 & Burning & $18 \mathrm{~kg}$ & $1,87 \times 10^{-3}$ \\
5 & Roundup & $0,02 \mathrm{~kg}$ & $2,93 \times 10^{1}$ \\
6 & Diazinon & $0,01 \mathrm{~kg}$ & $1,47 \times 10^{1}$ \\
\hline \multicolumn{4}{r}{ Total } \\
\hline
\end{tabular}

The total emissions from dryland paddy farming is $19,4 \times 10^{1}\left(\mathrm{~kg} \mathrm{CO}_{2} \mathrm{eq} / \mathrm{ha}\right)$. It's a challenge to reduce greenhouse gas emissions from dryland paddy farming as a part of agriculture. One of the ways to realizing it is use organic fertilizer and lower an-organic. Then, implementing mechanical control for weed and pest management. Integrated management of dryland paddy farming builds eco-friendly farming systems. This is a modified weed control scheme for optimize production and reduce emission.

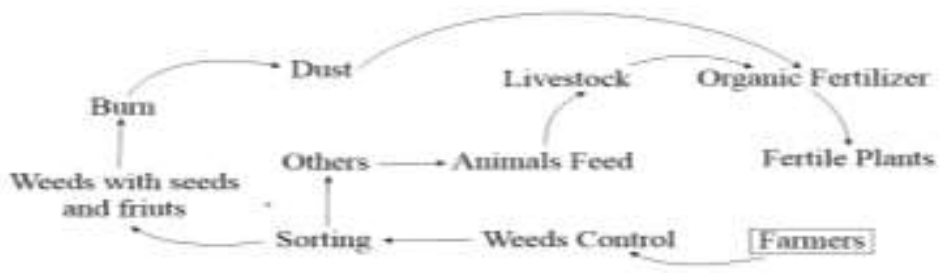

Fig. 2. Modification of weed control scheme.

Figure 2 shows the proposed modifications to the controlling system. These modifications optimize the existing controlling system, so the controlling can be done comprehensively and more effectively. The idea that is submitted by the researcher is that the post-mechanical control should sort by the weeds so that those containing fruit and seed may be burned, meaning there will be no longer be any weed growth potential. This technique is less harmful and is cheap [26]. Then, the weeds that have no fruit or seed can be used as feed for the livestock. Therefore, there will be two kinds of fertilizer: manure and ashes. Through this mechanism, farmers can ensure that the manure which is used is free from seed and fruit. The implementation of the controlling system serves as an alternative to control methods using pesticides, and thereby decreases both environmental pollution and production costs [27]. With this system, farming land can be fertilized more efficiently and weed disturbance can be minimalized. 


\section{Conclusion}

The fertilizer used in dryland paddy farming area is organic (manure) and an organic (NPK and Urea). Greenhouse gas emissions was released from dryland paddy farming are organic fertilizer $1,87 \times 10^{-3} \mathrm{~kg} \mathrm{CO}$ eq/ha and an organic fertilizer $15 \times 10^{1} \mathrm{~kg} \mathrm{CO}_{2} \mathrm{eq} / \mathrm{ha}$. Therefore, weed control that is applied by most of the dryland farmers is mechanical and chemical control. Chemical control released $4,4 \times 10^{1} \mathrm{~kg} \mathrm{CO}_{2}$ eq/ha and mechanical control 1,87 x 10${ }^{3} \mathrm{~kg} \mathrm{CO}_{2} \mathrm{eq} / \mathrm{ha}$. The totally of greenhouse gas emissions was released from dryland paddy farming in management phase is $19,4 \times 10^{1} \mathrm{~kg} \mathrm{CO} 2 \mathrm{eq} / \mathrm{ha}$. Organic fertilizer more friendly than an organic fertilizer and mechanical control more friendly than chemical control. Optimization dryland paddy farming and reducing emissions can be realized by life cycle perspective.

\section{Acknowledgements}

This work is supported by Hibah Publikasi Internasional Terindeks untuk Tugas Akhir Mahasiswa (PITTA) 2018 funded by the Directorate of Research and Community Engagement, University of Indonesia No. 2584/UN2.R3.1/HKP.05.00/2018.

\section{References}

1. Agricultural Statistic (Jakarta, Ministry of Agriculture Republic of Indonesia, 2016)

2. B.H. Bakar Malay J. of Sci 23 1-42 (2004)

3. T. Susanti, Suraida, H. Febriana Diversity of Invasive Plants in Kenali Forest Park Area Jambi City (Proceeding FMIPA UNILA, Lampung, 2013)

4. S.W. Utomo, Sutriyono, R. Redi, Ecology (Jakarta, Open University Publisher, 2014)

5. Local Regulation of Pacitan Regency Number 5 in 2011 About Long Term Development Plan (RPJP) Pacitan Regency in 2005-2025

6. Pacitan Agriculture Agency, Data of Crops and Horticulture in 2016 (2016)

7. B. Hafif, J. of Agr. Res. and Dev. 352 (2016)

8. G. Cornelisson, Jubaedah, N.L. Nurida, S.E. Hale, E. Martinsen, L. Silvani, J. Mulder, Sci. of the Tot. Env. 634 561-568 (2018)

9. P.K. Nayak, A.K. Nayak, B.B. Panda, B. Lal, P. Gautam, A. Poonman, M. Shahid, R. Tripathi, U. Kumar, S.D. Mohapatra, N.N. Jambhulkar, Ecol. Ind. 91 359-375 (2018)

10. M. Choudhary, A. Datta, H.S. Jat, A.K. Yadav, M.K. Gathala, T.B. Sapkota, A.K. Das, P.C. Sharma, M.L. Jat, R. Singh, J.K. Ladha, Geoderma 313 193-204 (2018)

11. M. Ariani, H. Yuliangingrum, P. Setyanto, J. Ilmu. Ling. 152 74-82 (2017)

12. M. Ariani, Inventarisasi Emisi Gas Rumah Kaca Sektor Pertanian dan Opsi Mitigasinya Dengan Pendekatan Marginal Abatement Cost ( Thesis, Institut Pertanian Bogor, 2014)

13. Suwondo, The Analysis of Greenhouse Gases Emission on Agriculture, Forestry and Other Land Use (Afolu) Sector in Riau Province. (Semirata FKIP Universitas Riau, 2014)

14. G. Pehnelt, C. Vietze, Env. Dev. Sustain. 15 429-479 (2013)

15. G. Pehnelt, C. Vietze, Env. Dev. Sustain. 15 429-479 (2013) 
16. M. Ariani, Inventarisasi Emisi Gas Rumah Kaca Sektor Pertanian dan Opsi Mitigasinya Dengan Pendekatan Marginal Abatement Cost ( Thesis, Institut Pertanian Bogor, 2014)

17. Suwondo, The Analysis of Greenhouse Gases Emission on Agriculture, Forestry and Other Land Use (Afolu) Sector in Riau Province. (Semirata FKIP Universitas Riau, 2014)

18. H.M.A. Hakim, W. Supartono, A. Suryandono, Ziraa'ah, 392 72-80 (2014)

19. M. Pergola, A. Persiani, A.M. Palese, V.D. Meo, V. Pastore, G. D’Adamo, G. Celano, App. Soil Ecol. 123, 744-750 (2018)

20. D. Asteria, Budidarmono, H. Herdiansyah, N.L. Ni'mah IOP Conf. Ser. Earth Environ. Sci. 126012146 (2018)

21. D. Lovarelli, J. Bacenetti, Soil. \& Til. Res. 174 156-168 (2017)

22. M.R. Gamez, J.C. Rodriguez, E.M.S. Rey, J. of Clean. Prod. 149 25-37 (2017)

23. M. Masi, A. Cimmino, A. Boari, A. Tuzi, M.C. Zonno, R. Baroncelli, M. Vurro, A. Evidente, J. Agr. Food Chem. 65 1124-1130 (2017)

24. T. Hu, P. Sorensen, E.M. Wahlstrom, N. Chirinda, B. Sharif, X. Li, J.E. Olesen, Agr, Ecos and Env. 251 141-148 (2018)

25. V.L. Sravani, Z. Abbas, P. Surya, Indo. American. J. of Phar. Sci. 49 2845-2852 (2017)

26. I. Gnanavel, S.K. Natarajan, Agr. Rev. 353 172-183 (2014)

27. M. Zargar, H.G. Plushyko, E.N. Pakina, M. Bayat, Ind. J. of Sci. \& Tech. 9 1 1-10 (2017) 